\title{
Baitolo, a native shipowner's vessel, and the participation of northern Iberians in the Laietanian wine-trade under the Late Republic
}

\author{
Alejandro G. Sinner and Joan Ferrer i Jané
}

This paper discusses a unique $\operatorname{artifact}^{1}$ of considerable archaeological, philological and historical value, as well as its implications for our understanding of the rôle that the native inhabitants of NE Spain, especially those known as the Laeetani (Plin., NH 3.3.21), played in the major economic undertaking that the export of wine from Tarraconensis in the 1st c. B.C. was to become. To do so, we first briefly describe the typological and physical characteristics of the lead stock and interpret the double Iberian inscription, baitolo, with which it was marked, probably a place-name, either that of the Ibero-Roman town of baitolo/Baetulo, which issued coins with the same legend (baitolo) in the second quarter of the 1st c. B.C., or the name of the nearby river, the modern Besòs. ${ }^{2}$ Subsequently, we contextualize the lead stock within the corpus of Greco-Roman lead stocks to show that no other specimen, either among stocks or any instrument or component of a ship's naval architecture, is known to have an inscription in the Iberian language. To contextualize the artifact, we will turn our attention to the native character of baitolo's population, always from a linguistic perspective, and discuss its importance as a key centre in the wine trade. Thereafter, we make an epigraphic and archaeological re-assessment of the prior evidence for the participation of the indigenous peoples of NE Hispania in all the phases (whether land or maritime) of the chaîne opératoire that resulted in the production and commercialization of large amounts of wine for Narbonne and elsewhere. First, we reconsider all the Iberian inscriptions that have a maritime context or that can be related to the production and commercialization of wine. Second, we examine the archaeological evidence, especially shipwrecks, suggesting that Iberian-speaking individuals during the 1st c. B.C. owned ships and participated in trade by sea, an activity that can now be confirmed thanks to the new lead stock (fig. 1), which is of small dimensions (77 cm long, $11 \mathrm{~cm}$ high, $8 \mathrm{~cm}$ in width in the central box) and of modest weight $(25.9 \mathrm{~kg})$.

\section{The lead stock: typology}

Anchors were lost not only in shipwrecks, but also on other occasions, as when one became snagged and had to be abandoned. The finding of an anchor or a stock does not necessarily imply the presence of a wreck; indeed, they are much more frequent as isolated finds, out of context, ${ }^{3}$ as is the case of the present example. A decontextualized stock cannot be securely dated from its technical characteristics alone, but the technology used to

1 It is now in the Guerra collection: see the Acknowledgements below.

2 An in-depth description of the inscription, along with the formation of the collection, the arguments in favour and against each possible interpretation, as well as arguments discarding the possibility that the stock is a forgery, can be found in J. Ferrer and A. G. Sinner, "Baitolo, una doble inscripción ibérica en un cepo de ancla de plomo del siglo I a.C.," Palaeohispanica 19 (2019) 147-67. In the present text, when discussing and citing Palaeohispanic inscriptions we have followed the conventions used and described in A. G. Sinner and J. Velaza (edd.), Palaeohispanic languages and epigraphies (Oxford 2019) vi.

3 In the "carta arqueológica", up to 33 locations of isolated anchors and 382 wrecks are mentioned: http://www.maccasc.cat/JACIMENTS/Jaciments-subaquatics-de-Catalunya. 


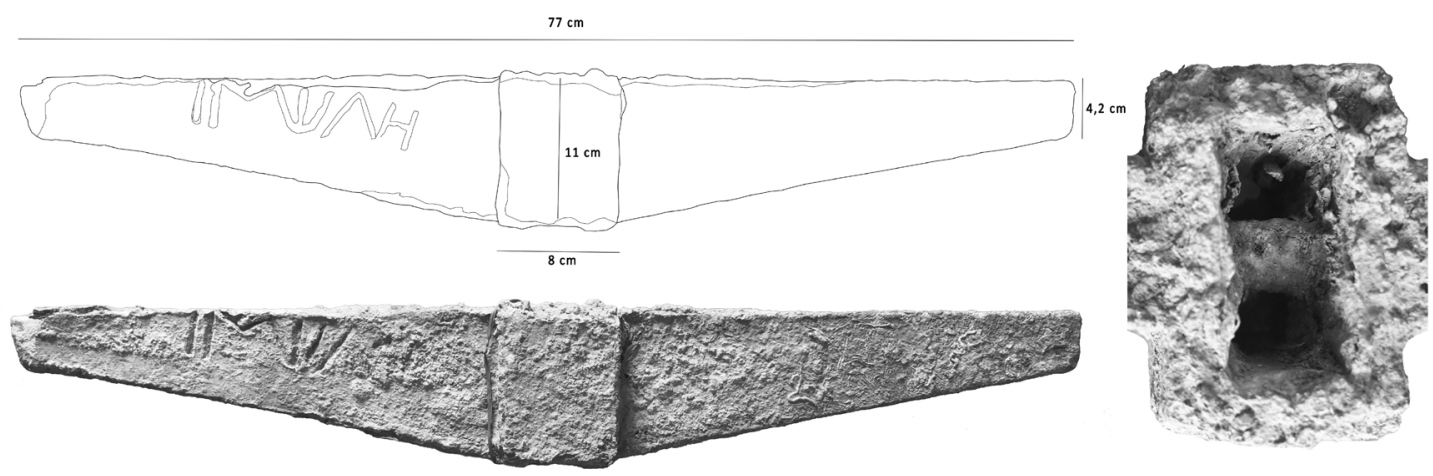

Fig. 1. Drawing and photograph of the lead stock.

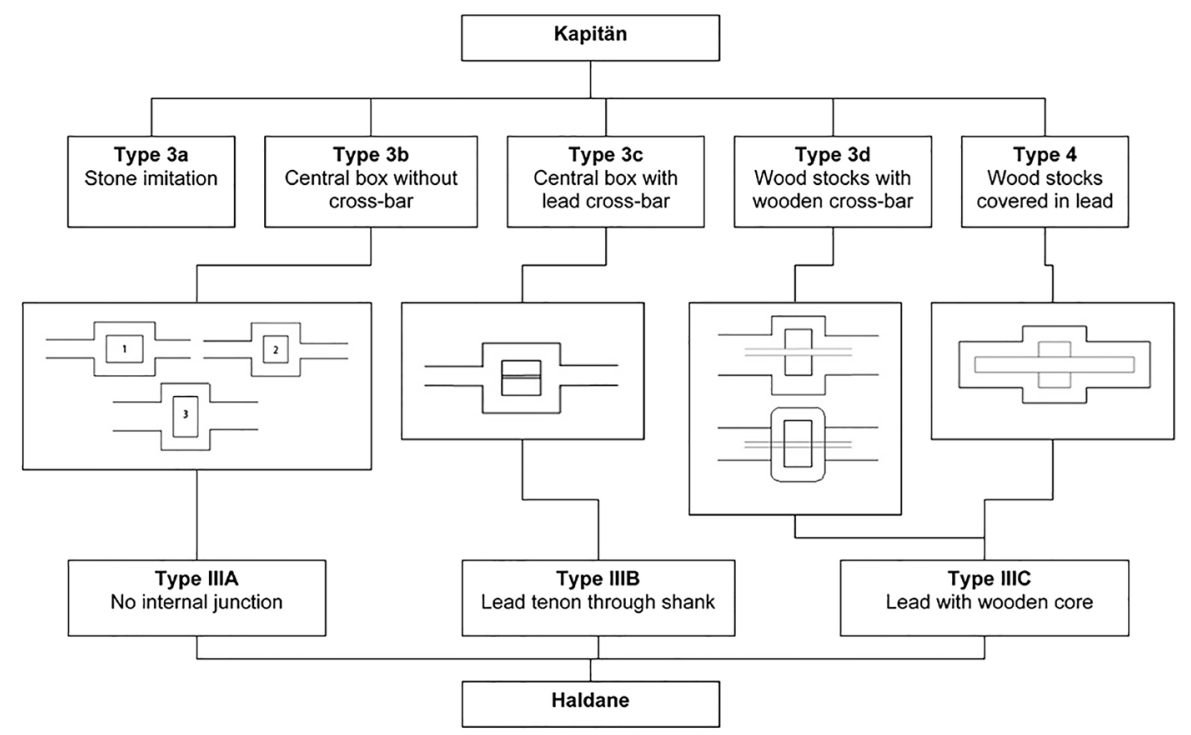

Fig. 2. Comparison of the two typologies of lead stocks by G. Kapitän and D. Haldane (E. Azzopardi, T. Gambin and R. Zerafa, "Ancient anchors from Malta and Gozo," Malta Arch. Rev. 9 [2008-9] 23, fig. 1).

make it can provide clues for a typological classification. Technologically, different types of stocks correspond to the shape of our object (fig. 2): stone, wood and lead-filled, wood and lead-plated, and solid lead. ${ }^{4}$ Our stock apparently used the last of these. Originally it must have been part of a wooden anchor with one or two arms. Stocks are generally connected at right angles to the axis of the arms and the shank, distributing the weight over the 4 sections formed by the cross axis of the stock and the anchor arms to ensure an efficient anchorage. Our stock presents a central box or "eye" which is placed around the shank, its internal dimensions reflecting the section of the shank. The crossbar in the central box shows that the stock was directly cast on the shank after a hole was made in it, so as to achieve a stronger joint between the two pieces. ${ }^{5}$ This was normally carried out by pouring molten lead into a ceramic and/or sand mould. ${ }^{6}$ Since lead stocks in wooden anchors are thought to have been used from the 5 th/4th c. B.C. to the 3 rd c. A.D., ${ }^{7}$ it is dif-

Ibid. 33-44.

6 D. Haldane, The wooden anchor (Ph.D. diss., Texas A\&M Univ. 1984); S. Gargiullo and E. Okely, Atlante archaeologico dei mari d'Italia, vol II (Rome 1993). 
ficult to date these objects with precision when found without an archaeological context. It has been suggested, however, that the proliferation of lead stocks (anchors) throughout the Mediterranean area could be linked to Roman control of the silver mines of Hispania after the Second Punic War, when Rome incorporated them into its ager publicus, ${ }^{8}$ as well as to the increasingly efficient mining techniques that produced lead as a by-product of silver. Two main typologies to classify these items have been proposed, by G. Kapitän and by D. Haldane (fig. 2), and our piece corresponds to Haldane's type IIIB or Kapitän's 3c, which is especially common in the W Mediterranean.

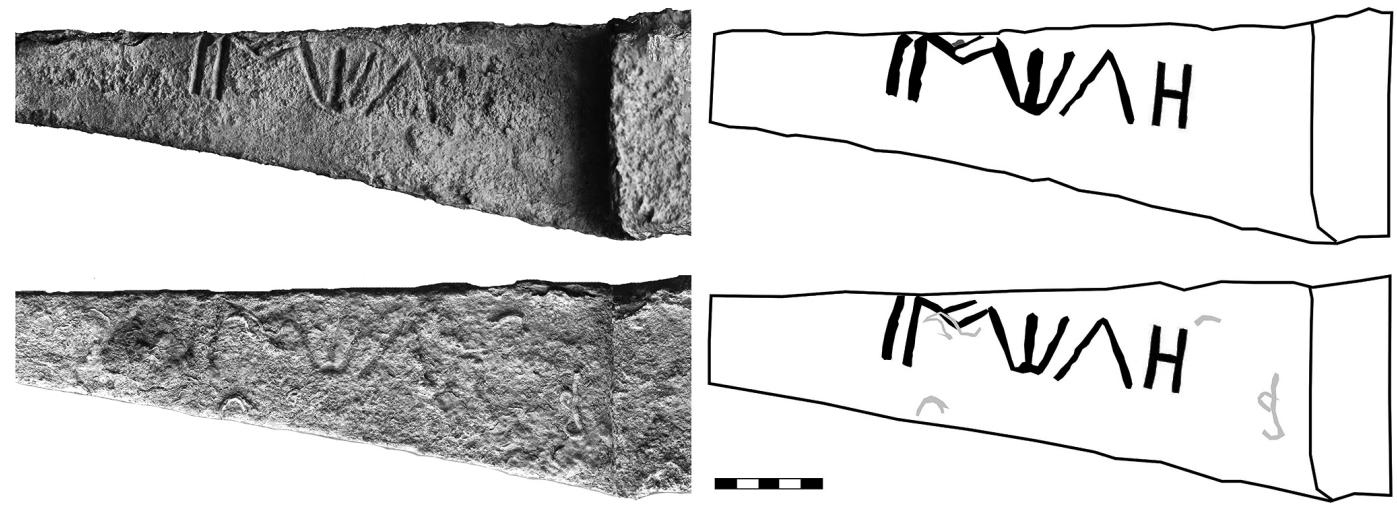

Fig. 3. Drawing and photograph of the two inscriptions: baitolo.

\section{The inscription}

The anchor has identical inscriptions on the opposite sides of its two arms: ba-i-to-l-o $(\mathrm{I}-\mathrm{N}-\mathrm{W}-\Gamma-\mathrm{H})$. The fact that both are identical in size, proportions and the way they are positioned hints that they could have been made with the help of a matrix and the cold incision technique, since the burrs in inscriptions made on hot metal cannot be detected. Further, the incisions are sharp and rectilinear, as seen in the signs ba and $\mathbf{i}$ (fig. 3). This would be the first time that this technique has been documented in the Iberian and in the Palaeohispanic epigraphic corpus. Only one other stamp on lead bearing an Iberian inscription (BDH B.41.05), corresponding to a double stamp on a label found in Badalona (baitolo/Baetulo), is known, where an individual, aiuniltun, is mentioned. ${ }^{9}$ A possible parallel for the engraving technique can be found on a lead stock from Blanes (Blandae), another town of the Laeetani, but that inscription uses Latin to inscribe the text: Septv. ${ }^{10}$ In general, the technique of stamping lead after it has cooled down is common in the countermarking of Hispanic lead ingots, marking some steps and providing information about some of the participants involved in their commercialization. ${ }^{11}$ Thus the technique is not

G. Purpura, Le ancore. Archaeogate il portale italiano di archeologia (2003), accessible at: http:// www1.unipa.it/dipstdir/portale/subacquea/ANCORE/index.html (last viewed 25 July, 2019).

B. Díaz and J. A. Antolinos, "The organisation of mining and metal production in Carthago Nova between the Late Republic and Early Empire," Athenaeum 101 (2013) 535-53; A. Mateo, Observaciones sobre el régimen jurídico de la minería en tierras públicas en época romana (Santiago de Compostela 2001).

9 M. Comas, P. Padrós and J. Velaza, “Un plomo con doble inscripción ibérica localizado en Baetulo (Badalona)," Palaeohispanica 2 (2002) 327-31.

10 E. Ripoll, “Notas de arqueología de Cataluña y Baleares: Blanes," Ampurias 24 (1962) 311-13.

11 C. Domergue, "Production et commerce des métaux dans le monde romain: l'exemple des métaux hispaniques d'après l'épigraphie des lingots," in Actes VIIe Rencontre franco-italienne 
alien technologically or chronologically to our area of study.

The signs that make up the inscription are ba1, i1 with short, diagonal upper strokes, to1 with its outer strokes tilted slightly outwards, $\mathbf{1 1}$ and $\mathbf{o 1}$ (due to the poor visibility of the inner stroke it is unclear whether it is strictly horizontal or has any inclination) (fig. 3). Palaeographic analysis indicates use of the non-dual Iberian writing system, a script typical of the 2nd-1st c. B.C., ${ }^{12}$ and particularly of bronze coin legends. In fact, the place-name baitolo is known from coinage issued during the first quarter of the 1st c. B.C. by the town of baitolo/Baetulo (Badalona) (BDH Mon-8) (see below). Thus our inscription too is probably a place-name for a town or river. Support for the former is based on the coin legends, as most of the Iberian ones in NE Spain of the late 2nd/early 1st c. B.C., including baitolo, identify the issuing authority, which almost always corresponds to the town. ${ }^{13}$ The latter stems from Mela (Chorographia 2.90), who mentions both the town and the river Baetulo (the Latin form of baitolo).

The possibility that baitolo is acting as a personal name is theoretically feasible, but it seems unlikely due to the low frequency of the particles bai and tolo as onomastic formants in the Iberian language. ${ }^{14}$ Further, in the three cases (E.7.1; K.28.1; BDH GI 10.07) in which some of the place-names present in coin legends appear in non-monetary inscriptions, their function as toponyms is always clear. Although it is true that place-names and personal names share formants, they form separate corpora once the formants are combined. The baitolo on our lead stock could also possibly be referring to a divinity. The main argument would be that baitolo is the name of a river that could have had an associated homonym divinity. While the association of deities with rivers has parallels in IndoEuropean Hispania, ${ }^{15}$ it has not been documented that this practice was also adopted by the Iberian peoples. While Iberian divinities are scarcely mentioned in Latin inscriptions, when they appear they also reflect the two-part structure of personal and place-names, as is the case of the deities Sertundo (seŕtun + do), ${ }^{16}$ Betatun (bete + atun) ${ }^{17}$ and Salaeco (śalai + ko). ${ }^{18}$ In short, in the current state of knowledge there are no compelling arguments to opt for this interpretation as the most feasible.

sur l'épigraphie du monde romain, 1992 (Rome 1994) 61-91; C. Rico, "Réflexions sur le commerce d'exportation des métaux à l'époque romaine. La logique du stockage," in J. Arce and B. Goffaux (edd.), Horrea d'Hispanie et de la Méditerranée romaine (Madrid 2011) 41-64; C. Domergue and C. Rico, “L'approvisionnement en métaux de l'Occident méditerranéen à la fin de la République et sous le Haut-Empire," in B. Woytek (dir.), Infrastructure and distribution in ancient economies (Vienna 2018) 193-252.

12 J. Ferrer i Jané, "Novetats sobre el sistema dual de diferenciació gràfica de les oclusives," Palaeohispanica 5 (2005) 957-82.

13 J. Ferrer i Jané, "La lengua de las leyendas monetales ibéricas," in A. G. Sinner (ed.), La moneda de los Iberos. Ilturo y los talleres layetanos (Barcelona 2012) 28-87; P. P. Ripollès and A. G. Sinner, "Coin evidence for Palaeohispanic languages," in Sinner and Velaza (supra n.2) 365-95. For an in-depth analysis of the possible segmentations of the text baitolo, see Ferrer and Sinner (supra n.2) 149-55.

J. C. Olivares, "Los dioses soberanos y los ríos en la religión indígena de la Hispania indoeuropea," Gerión 18 (2000) 191-212.

J. C. Vidal, "Interpretació ibèrica de dos teònims preromans del nord-est peninsular," Revista d'Arqueologia de Ponent 26 (2016) 195-204.

17 S. Corzo, M. Pastor, A. U. Stylow and J. Untermann, "Betatun: la primera divinidad ibérica identificada," Palaeohispanica 7 (2007) 251-62.

18 J. Velaza, "Salaeco: un teónimo ibérico," ZPE 194 (2015) 290-91. 


\section{Inscribed lead stocks: interpretation and epigraphic techniques}

Underwater finds in the Mediterranean provide a substantial body (as many as 90 to date $^{19}$ ) of inscribed Greco-Roman lead stocks. ${ }^{20}$ Most (67\%) of the inscriptions have been recorded on Italian shores, but a dozen (13\%) come from the coasts of the Iberian peninsula. Of our total sample, $72 \%$ of the lead stocks bear Latin inscriptions, $26 \%$ Greek, with only 1 inscription each in Punic ${ }^{21}$ and Neo-Punic. ${ }^{22}$ According to their interpreters, personal names dominate (59\%), followed by theonyms (39\%); we also find two references to Roman legions. Theonyms dominate among the inscriptions in Greek, while in the Latin ones inscriptions interpreted as names of deities amount to fewer than $20 \%$. Among Latin inscriptions on lead stocks it is most common to find a personal name, usually interpreted as the ship's owner. A good example is the stock with the inscription L. Ferranivs Celler (A15) from Populonia; the name appears in two more wrecks, at Foce Verde (Latina) and at Cullera (Valencia). The anchor with the inscription of Sextvs Arrivs (A8) from the Dramont wreck (Saint Raphaël) is also of considerable interest; two stocks with the same inscription and belonging to the same vessel appeared. Its cargo contained, among other commodities, Dressel 1B amphoras, some bearing the same inscription as that on the opercula that sealed the vessels, which probably indicates that the shipowner and the proprietor of at least part of the cargo were one and the same. ${ }^{23}$ On exceptional occasions the name inscribed could strictly be its manufacturer, as with L. Antoni(vs) Felix followed by the explicit fecit at Hvar (Croatia). ${ }^{24}$ The next most common case is to find on the stock the name of a divinity and/ or an epithet that represents and/or characterizes the deity. ${ }^{25}$ Among the Greek inscriptions examples include: "Ho $\alpha$ from Reggio Calabria (I19), 'Ho $\alpha \kappa \lambda \tilde{\eta} \varsigma$ from Capo Zafferano (Palermo) (I25), $\Sigma \omega \epsilon \varepsilon\left\llcorner\varrho \alpha\right.$, referring to A $\theta \eta v \tilde{\alpha}$, from Monasterace (Reggio Calabria) ${ }^{26}$ and 6 other locations (I10-I15); among the Latin ones we find Vesta from Capo Vaticano (Calabria) (I17), Venus from Maratea (I9) and Salvia from Ventotene (Latina) (I16), as well as others (fig. 4). On some occasions double dedications are recorded, such as Ceres/Isis from Nora (I22) and Isis/Sarapis on the stock recovered off Malta. ${ }^{27}$ The occasional references to legions include Leg XVI at Mainz and VI Alavdae at Duisburg. ${ }^{28}$ Finally, an inscription recently found at Messina contains a message describing the objective of the anchor: Salvtem. ${ }^{29}$

19 P. A. Gianfrotta, "Ancore romane: nuovi materiali per lo studio dei traffici marittimi," in J. H. D'Arms and E. C. Kopff (edd.), The seaborne commerce of ancient Rome (MAAR 36; 1980) 10316; A. Hesnard and P. A. Gianfrotta, "Les bouchons d'amphore en pouzzolane," in Anfore romane e storia economica (Rome 1989) 393-441; P. A. Gianfrotta, "Notte di epigrafia marittima. Aggiornamenti su tappi d'anfora, ceppi d'ancora e altro," in Epigrafia della produzione e della distribuzione (CollEFR 193; 1994) 591-608; A. Fenet, Les dieux olympiens et la mer: espaces et pratiques cultuelles (CollEFR 509; 2016), with review by P. A. Gianfrotta at ArchCl 68 (2017) 649-56.

20 We have not considered stone anchors (Fenet ibid. 596) and those containing numerals and decorations (ibid. 573).

21 J. M. Solà Solé, “Miscelánea púnico-hispánica IV," Sefarad 27 (1967) 28-33.

22 F. Briquel, "Première ancre à inscription néopunique," Orientalia 76 (2007) 24-29.

23 Gianfrotta 1994 (supra n.19) 591.

24 Ibid. 600.

25 The number in brackets refers to Fenet's catalogue (supra n.19).

26 Gianfrotta 2017 (supra n.19) 653.

27 Ibid. 654.

28 Ibid. 110.

29 R. La Roca and F. Oliveri, "Le ancore di salvezza," Mirabilia maris: tesori dai mari di Sicilia (Palermo 2016) 245. 


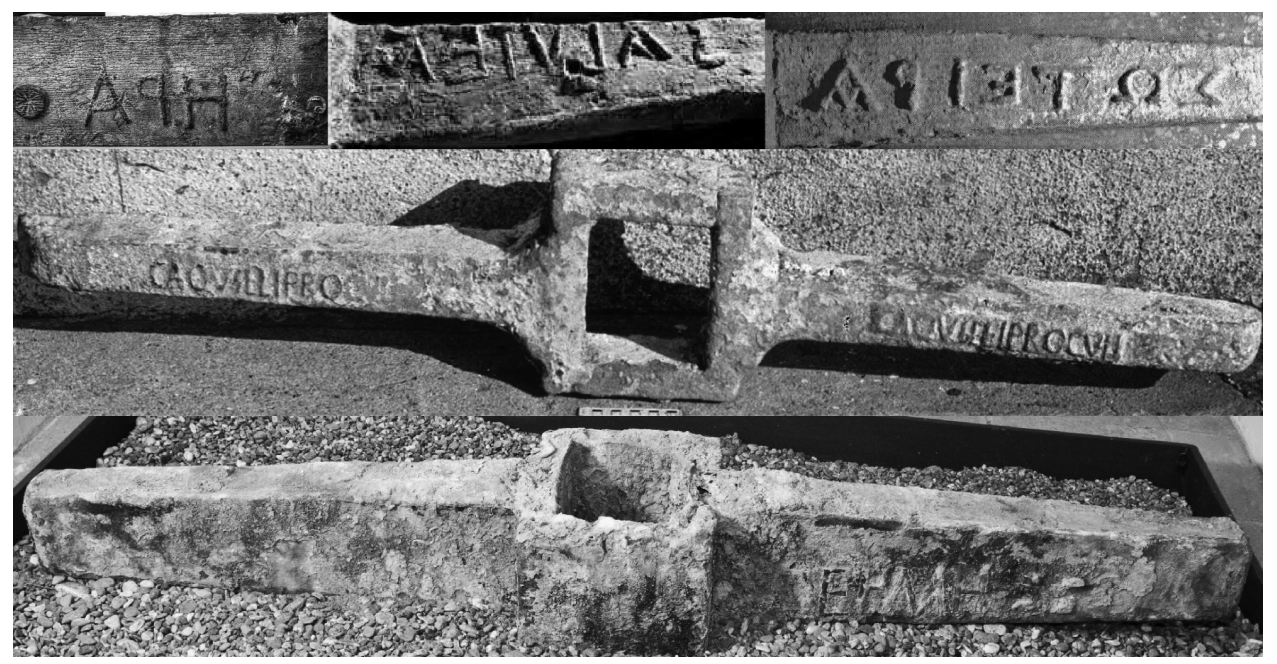

Fig. 4. Examples of inscribed lead stocks "Hpa (Museo Archeologico Nazionale Di Reggio Calabria), Salvtem

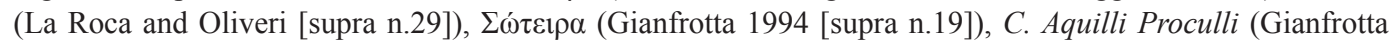
1994 [supra n.19]) and Epme (Museo del Mare, Cetraro).

When the name on the anchor corresponds to a divinity, it is thought that it also acts as the name of the ship; ${ }^{30}$ indeed, some names recorded on anchors appear in documents listing ships in the Misene fleet: ${ }^{31}$ Vesta, Venus, Salvia, Ceres and Isis are examples on both triremes and quadriremes. This could also be the case with an inscription written below

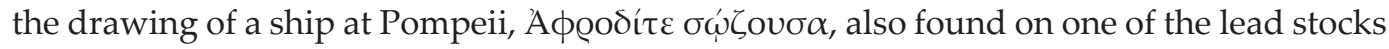
from Cabo de Palos. ${ }^{32}$ An epithet of Aphrodite (Evं $\pi \lambda$ ot $\alpha$ ) on an anchor from Fabignana ${ }^{33}$ coincides with the name of one of the triremes listed in the Tabulae Curatorum Navalium (IG II $\left.^{2} 1631,167-74\right)$. Generally on Latin-inscribed stocks a large number of vessels received deity names such as Minerva. If a place-name was inscribed, the most common practice was to employ the names of rivers (e.g., Nilvs). ${ }^{34}$

Most texts (83\%) are presented in relief, of which at least $25 \%$ appear reversed as the inversion in the mould was not carried out correctly; the rest $(17 \%)$ would have been incised in the cold metal, as is the case of our stock. The inscription usually appears on only one of the 4 sides, the widest being preferred, although sometimes the narrowest is chosen, as in the case of C. Aqvilli Procolli from Castelabate. When the inscription is double, as in the Maltese case of Isis/Serapis, ${ }^{35}$ it can occupy the adjacent side of the other arm, the opposite side of the same arm, or the opposite side of the other arm, as in the cases of our baitolo and the one of Zeus Hypatos in the British Museum. A repeated text has been previously documented just twice: C. Aqvilli Proculli and L. Ferranio Cellero from Cullera (here on consecutive sides). Other exceptional cases come from Villasmius (Calabria) (I12), with the text Sotira, inscribed on the 4 sides of the arms, and from Cabo de Palos dedicated to

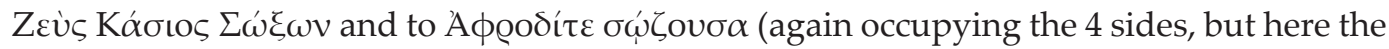
result of the length of the text [I7]).

30 Gianfrotta 1980 (supra n.19) 109; Gianfrotta 2017 (supra n.19) 654; Fenet (supra n.19) 320.

31 Gianfrotta 1980 (supra n.19) 110.

32 Ibid. 109.

33 La Roca and Oliveri (supra n.29) 243-45.

34 L. Casson, Ships and seamanship in the ancient world (Baltimore, MD 1995) 358-59.

35 Gianfrotta 2017 (supra n.19). 


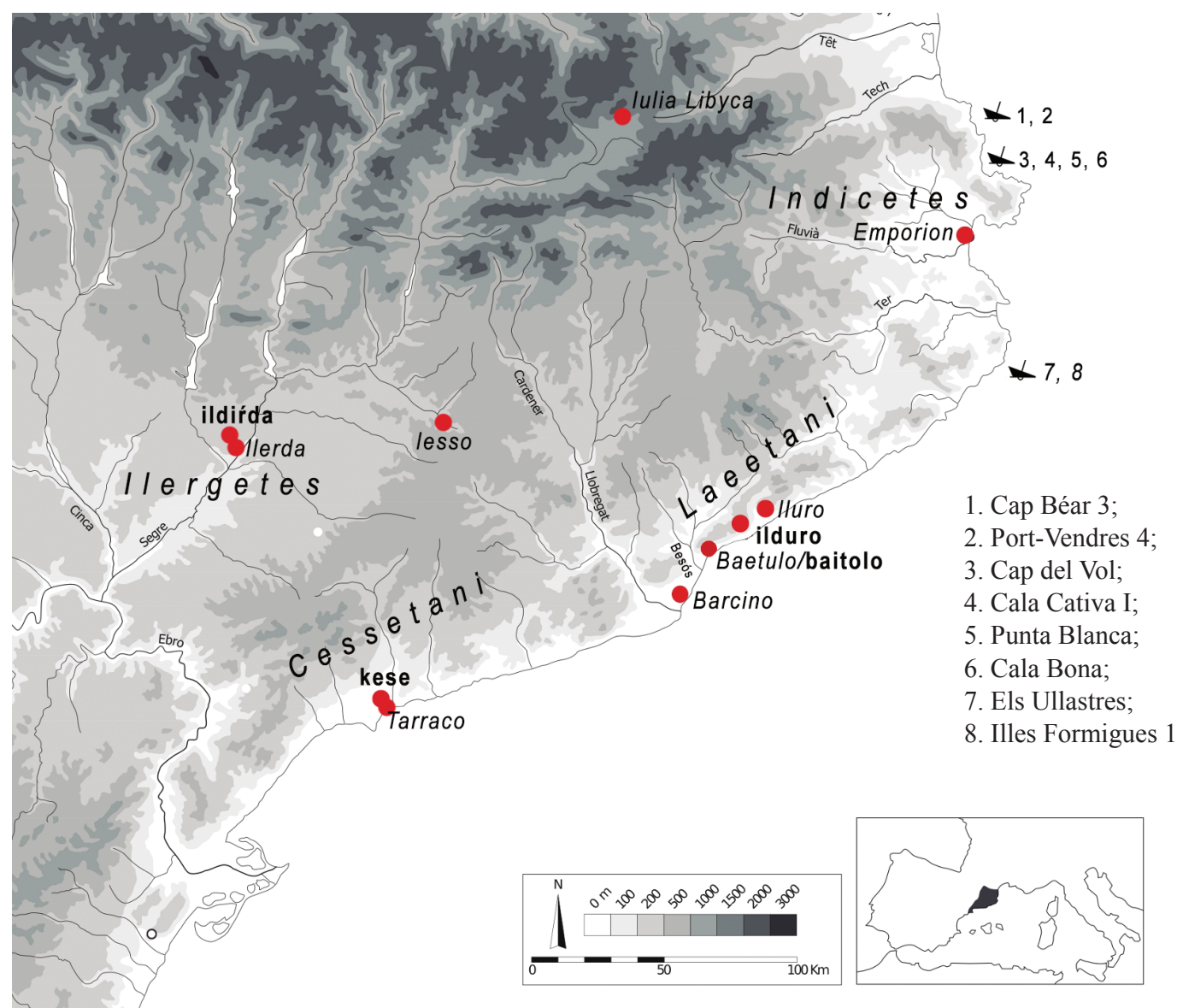

Fig. 5. The main Iberian oppida, Roman towns and wrecks discussed in the text.

\section{Archaeological and historical context: baitolo/Baetulo}

The 1st-c. B.C. sources (Plin., NH 3.3.22; Ptol. 2.16.18; Mela 2.90) identify Baetulo (Badalona, the Latin adaptation of the Iberian baitolo) as a town located between Barcino (Barcelona; Iberian baŕkeno) and Iluro (Mataró; Iberian ilduro) (fig. 5), but also as the name of a nearby river, which may well have given its name to the town. The history of baitolo/ Baetulo recalls that of many other towns in NE Spain, such as ilduro/Iluro, ildiŕda/Ilerda or kese/Tarraco (fig. 5). Each of these settlements was the urban nucleus of a series of Archaic proto-states (kese for the Cessetani, ildiŕda for the Ilergetes, ilduro for the Laeetani), which, at least from the 4 th c. B.C. onwards, centralized their power at a specific oppidum and managed a rational exploitation of the surrounding territory. Even if the Roman conquest cut short their evolution, an important period of growth, characterized by the arrival of Italic products and comparable architectural styles and building techniques, took place during the second half of the 2nd c. B.C. Next seems to have come the foundation of new towns in the first quarter of the 1st c. B.C., either on the same site as the oppidum or nearby; 36 for baitolo/Baetulo, it is possible to suggest that the Iron Age oppidum was the nearby hillfort

36 For the case of ilduro, see A. G. Sinner, "Cultural contacts and identity construction: a colonial context in NE Spain (2nd-early 1st c. B.C.)," JRA 28 (2015) 7-38. For a general overview of NE Spain, see F. Pina Polo, “¿Existió una política romana de urbanización en el nordeste de la península Ibérica?," Habis 24 (1993) 77-94. 
of Turó d'en Boscà. The mint of baitolo (BDH Mon-8), however, must be related to the Roman town founded ex novo on Turó d'en Rosés just $2 \mathrm{~km}$ to the south. ${ }^{37}$ To judge from the coin legends, the new town was called baitolo, subsequently the municipum of Baetulo. Most inhabitants of baitolo seem to have been natives since all the inscriptions belonging to the town's foundation phases and most of the 1st c. B.C. use the Iberian script. ${ }^{38}$ Similarly at ilduro/Iluro, 80 inscriptions on ceramics, most made post cocturam and interpreted as ownership marks, use the Iberian script. ${ }^{39}$ It is quite possible that even the élites and magistrates in the newly-founded towns were also natives; they were the ones who decided upon the coin legends which used the Iberian script. ${ }^{40}$ Indigenous individuals within municipal élites have also been documented in Iulia Libyca, ${ }^{41}$ another new foundation (fig. 5); here three magistrates (quattuorviri) were still using Iberian onomastics during the Augustan period, while a fourth having a Latin name maintained an Iberian filiation. ${ }^{42}$ Literary and epigraphic references to the Latin name Baetulo date from at least the late 1st c. A.D., as does Baetulonenses, mentioned in an inscription of A.D. 98 (IRC I, 139). Thus not only do the double denomination of baitolo/Baetulo and the term Ibero-Roman seem suitable, but it should not surprise us, based on the composition of the population, that a lead stock probably made here uses the Iberian script.

The oppidum at the Turó d'en Boscà was abandoned around 100 B.C., even if residual occupation can be detected down to 90 B.C. ${ }^{43}$ There is a certain consensus that the foundation of baitolo/Baetulo took place between $90 / 80$ and $80 / 70$ B.C., ${ }^{44}$ but a suburbium already dating to the first quarter of the 1st c. B.C. at Illa Fradera was built with structures of Italic style and oriented according to the later town's layout. This suburb was replaced in the mid1st c. B.C. by a workshop specializing in Pascual 1 amphoras, ${ }^{45}$ a form that replaced the Tarraconense 1 , both widely used to transport the local wine.

From its initial stages, baitolo/Baetulo profited from the production and commercialization of wine. With nearby workshops such as those of Can Peixau linked to M. Porci stamps, the one at Illa Fradera and one recently excavated at La Estrella, ${ }^{46}$ baitolo/Baetulo

P. Padrós, “Las cecas layetanas. La ceca de Baitolo," in Sinner (supra n.13) 44-54.

F. Torra, "Les inscripcions ibèriques a la ciutat de Baetulo," Carrer dels arbres 20 (2009) 7-24.

A. G. Sinner and J. Ferrer i Jané, "Del oppidum de Burriac a las termas de Ca l'Arnau. Una aproximación a la lengua y a la identidad de los habitantes de Ilduro (Cabrera de Mar, Barcelona)," AEspArq 89 (2016) 199-223; iid., "Novedades epigráficas de Ilduro (Cabrera de Mar, Barcelona)," Palaeohispanica 18 (2018) 203-16; J. García, Gènesi, fundació i període republicà de la ciutat romana d'Iluro (Hispania Tarraconensis) (Ph.D. diss., Universitat de Barcelona 2014).

Sinner and Ferrer i Jané 2016 (supra n.39); L. Amela, "baitolo," in Varia Nummorum 8 (Seville 2018) 85-97.

J. Ferrer i Jané, O. Olesti and J. Velaza, “Nuevas inscripciones rupestres latinas de Oceja y los IIIIviri ibéricos de Iulia Lybica," DHA 44 (2018) 169-95.

Bella $\cdot$ Gaisco $\cdot f($ ilius) / Bella $\cdot$ Bastobles $\cdot f($ ilius ) / Adinildir · Betepe[- · f(ilius)] / Corneli · Erdoild[ir . f(ilius) ] / scriptum $\cdot$ est $\cdot$ IIII $\cdot$ viratum.

3 D. Zamora, Les ceràmiques de vernís negre del poblat ibèric del Turó d'en Boscà (Igualada 1995); P. Padrós, "Algunos ejemplos de la relación existente entre cecas ibéricas y fundaciones tardorepublicanas en el noreste de la Hispania Citerior," in Actas XIII Congreso int. de Numismática (Madrid 2005) 523-30.

Padrós (supra n.37) 49.

Ibid. 51; F. Antequera, P. Padrós, A. Rigo and D. Vázquez, "El suburbium occidental de Baetulo," in D. Vaquerizo (ed.), Las áreas suburbanas en la ciudad histórica (Córdoba 2010) 173-210.

Here the infrastructure for processing the grapes (presses, channels, lacus, etc.) has been recorded, together with several stamps of $M$. Porci and a stone inscription also mentioning 
probably acted as a distribution centre for the products of its hinterland. ${ }^{47}$ Archaeometric studies carried out at the wrecks of Cap del Vol, ${ }^{48}$ Els Ullastres and Port-Vendres 4 and 5 (fig. $5)^{49}$ confirm that a large part of the amphoras carried came from the workshops in the town's territory. This distribution will have required a port and related infrastructures that may have been detected in the SW part of the town. Large stones created a slope that has been interpreted as a loading/unloading zone ${ }^{50}$ where two large amphora deposits and 3 dolia were excavated. ${ }^{51}$ Some scholars consider that the estuary of the Besòs could have served as a complementary port. ${ }^{52}$

Relevant again here is the coinage minted by baitolo (fig. 6, nos. 1-7), structured in 7 issues ${ }^{53}$ produced during the first quarter of the 1st c. B.C. Further, three plomos monetiformes ${ }^{54}$
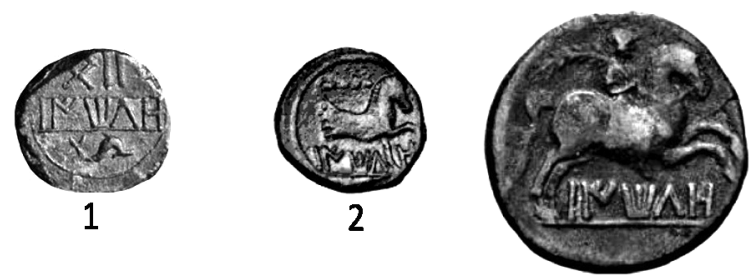

3

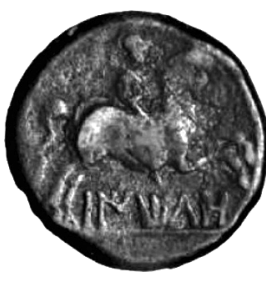

4
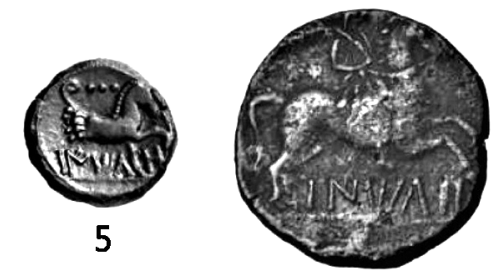

6
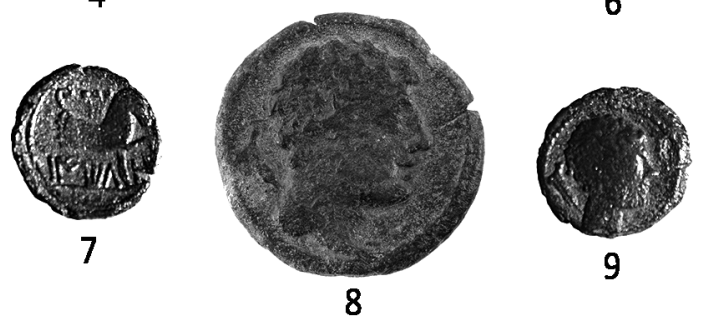

Fig. 6. nos. 1-7. Issues minted by baitolo (Padrós [supra n.39]; Amela [supra n.42]).

nos. 8-9. Issue from baitolo with rudder mark on reverse.

the name Porci, which seems to indicate that the facility belonged to this individual.: https:// www.nationalgeographic.com.es/historia/aparece-gran-villa-romana-badalona-cercabarcelona_14568/4\#slide-3 (agosto 2019).

47 M. Comas and C. Carreras, "Les àmfores de la Laietània: estat de la qüestió," in Monografies MAC-Barcelona 8 (2008) 177-88.

48 G. Vivar, C. de Juan and R. Geli, "Cap del Vol. Un producto, un barco y un comercio del Conventus Tarraconensis en época de Augusto," in X. Nieto, A. Ramírez and P. Recio (edd.), I Congreso de Arqueología náutica y subacuática española (Cartagena 2013) 97-108.

49 V. Martínez Ferreras, “Las ánforas vinarias de la Layetania. Dinámicas de producción y difusión comercial en el siglo I a.C. y I d.C.," in R. Járrega and P. Berni (edd.), Amphorae ex Hispania (Monografías Ex Officina Hispana; Tarragona 2016) 146.

50 M. Comas, "La producció i el comerç del vi a Baetulo. Estat de la questió," in El vi a l'Antiguitat: economia, producció i comerç al Mediterrani occidental (Badalona 1998) 219-32.

51 M. Comas and P. Padrós, "Deux grands dépotoirs d'amphores léétaniennes, bétiques et gauloises hors les murs de la ville de Baetulo (Badalona)," in SFECAG, Actes du Congrès de L'Escala-Empúries (L'Escala 2008) 75-86.

52 P. Izquierdo, "Els ports del litoral tarraconense i el seu paper en el comerç del ví," in El vi tarraconense i laietà: ahir i avui (Tarragona 2009) 185.

53 P. Padrós, "El protagonisme de la moneda ibèrica a les ciutats romanes tardo-republicanes: Baetulo i la seca de Baitolo," in VI Curs d'Història Monetària d'Hispània. Funció i producció de les seques indígenes (Barcelona 2002) 105-23; Padrós (supra n.37) 53; Amela (supra n.40).

54 On plomos monetifomes, see A. Casariego, G. Cores and F. Pliego, Catálogo de plomos monetiformes de la Hispania antigua (Madrid 1987); L. Villaronga, "Plomos monetiformes de la Citerior de época romano-republicana," RivItalNum 95 (1994) 307-20; C. Stannard, A. G. Sinner, N. Moncunill and J. Ferrer, "A plomo monetiforme from the Iberian settlement of Cerro Lucena 
imitating the iconography of the sextantes of the mint's first issue, with a dolphin and a value mark be II on the reverse, were discovered at Illa Fradera. ${ }^{55}$ The mint of baitolo occasionally used a rudder as an issue mark (fig. 6, nos. 8-9), a further reference to maritime trade. The designs chosen for the Iberian coinages, issue marks included, will have spread an ideological message at political, economic and/or religious levels. ${ }^{56}$ Issue marks are normally expressed by a symbolic complement (although there are also alphabetic ones ${ }^{57}$ ) that varies from issue to issue: caduceus, amphora, palm, rudder, etc. While the mint of kese was a source of iconographic inspiration for other Iberian mints, the unusual choice at baitolo of a rudder is significant and has already been related to a protective divinity of navigation ${ }^{58}$ or seen as representing the town's maritime character. ${ }^{59}$ The mark may well represent the town's link to navigation and the wine trade towards Gaul and elsewhere. The Cap del Vol and Cala Cativa I wrecks (see below), carrying amphoras produced in the town and its hinterland, are examples of its failed shipments.

\section{Other contemporary wrecks}

It is impossible to determine the specific origin of our lead stock, but a few wrecks from which the stocks of their anchors have been recovered may help us gain a better appreciation of the archaeological context of ours. ${ }^{60}$ With respect to the chronology, the palaeography of the signs places us within the general framework of the non-dual writing system characteristic of the 2 nd and 1st c. B.C. The parallels with the first coin issues of baitolo suggest a terminus post quem of the beginning of the 1st c. B.C. The end of the 1st c. B.C., when Iberian inscriptions finally fell out of use, even though their use was already sporadic during the second half of that century, seems to us a plausible terminus ante quem. Since the oldest evidence for wine exports from baitolo/Baetulo corresponds to the mid-1st c. B.C., this would be the most likely context for the ship that once carried our lead stock. With respect to the geography, materials in the Guerra collection come mainly from the Alt and Baix Empordà, although some come from El Maresme, such as those of the Calella I wreck. The dimensions and weight of our stock correspond to a small ship, ${ }^{61}$ which would match

(Enguera, Valencia) with a north-eastern Iberian legend, and the Italo-Baetican series," J. Arch. Numismatics 7 (2017) 59-106.

Padrós (supra n.37) 53; J. Ferrer i Jané, “A propòsit d'un sisè de bronze de baitolo amb la llegenda be II," Acta Numismàtica 44 (2014) 57-69; Amela (supra n.40).

M. Gozalbes, "Divinitats i imatges sagrades," in Els Ibers, cultura i moneda (Barcelona 2010) 64-69; id., "Divinitats i herois a les emissions iberes i celtiberes de la Citerior," in Déus i mites de l'Antiguitat: l'evidència de la moneda d'Hispània (Barcelona 2012) 46-51.

57 Ferrer i Jané (supra n.13).

58 E. Collantes, Historia de las cecas de Hispania antigua (Madrid 1997).

$59 \quad$ Amela (supra n.40) 87.

60 At least the Cala Culip III wreck (Cadaqués) carried Pascual 1 amphoras of c.40 kg: P. Dell'Amico and F. Pallarés, "Le anfore della Laietania. Appunti e riflessioni," Archeologia Marittima Mediterranea 4 (2007) 57; M. Frontini, El yacimiento subacuático de Cala Culip (Universitat de Barcelona 2019). The del Golfet I (El Port de la Selva) wreck, also transporting Pascual 1, was apparently not recovered: G. Vivar, "Memòria de la carta arqueològica subaquàtica de la comarca de l'Alt Empordà (2011)," in Centre d'Arqueologia Subaquàtica de Catalunya 2011. From the De Cap del Vol wreck we have news of a lead stock weighing $103 \mathrm{~kg}$ that is currently in a private collection (we thank Rut Geli [CASC] for this information).

61 Recorded in the database of the Museus de la Generalitat de Catalunya are 30 lead stocks, almost all with no known provenance. Half are less than $1 \mathrm{~m}$ in length; only 5 are under $77 \mathrm{~cm}$ : http://museusenlinia.gencat.cat/eMP/eMuseumPlus. 
the estimated dimensions $(10-25 \mathrm{~m})^{62}$ of ships engaged in coastal cabotage, such as Cala Cativa I and Cap del Vol (see below). A few wrecks with an established chronology offer a parallel for the ship that once carried our stock: first, ships transporting Tarraconense/ Layetana 1 amphoras, ${ }^{63}$ such as Illes Formigues 1 (Palamós), Cala Bona 1 (Cadaqués) and Cap Béar 3 (Port-Vendres); then perhaps also some of the oldest of the $c .20$ ships (even if already towards the limits of our likely chronology) that carried Pascual 1 amphoras, ${ }^{64}$ such as Port-Vendres 4 and Els Ullastres (Llafranc), both with amphoras produced at baitolo/Baetulo. The Cala Cativa (El Port de la Selva) wreck, from which there are reports of two lead stocks, ${ }^{65}$ may provide the best parallel.

\section{Iberian epigraphy in maritime contexts}

Is there further evidence for the participation by indigenous peoples in this area in the lucrative wine trade? An inscription (fig. 7) on a Layetana 1/Tarraconense 1 amphora mentioning tautibeleś (BDH GI. 17.03), ${ }^{66}$ a personal name, was recovered in unknown circumstances from a shipwreck on the Costa Brava, probably the Cala Bona I wreck which is dated to the third quarter of the 1st c. B.C. ${ }^{67}$ The amphora, which also presents the Latin stamp Mevi, has been attributed to the workshop located at Fenals (Lloret de Mar). The stamp Mevi was made during the vessel's production, while the post coctionem graffito ${ }^{68}$ was probably marking one of the steps in the commercialization process, perhaps identifying the owner (tautibeleś) of one of the lots in the ship's cargo, since it was made before the amphora was loaded at the port of origin. Several of the Tarraconense 1 amphoras in the Guerra collection come from the same wreck $^{69}$ and bear the same stamp: Mevi. The QMevi

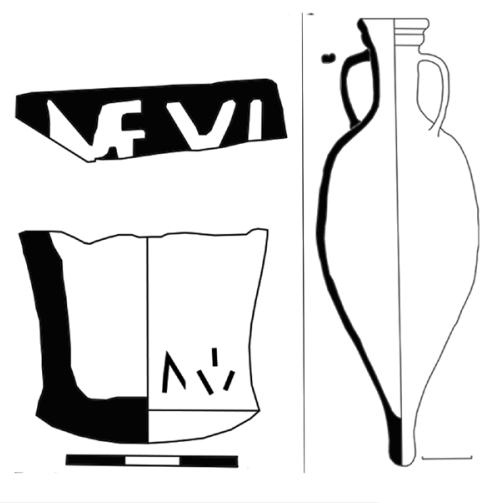

Fig. 7. Iberian graffiti with the text le (left) (after Solier [supra 75]) and tautibeleś (right) (after Vilà [infra n.71]).

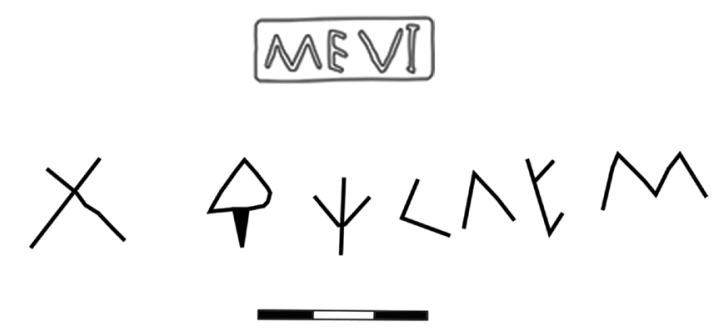

62 P. Izquierdo, “Condiciones y conocimientos náutico-marinas en la Antigüedad," in J. M. López and M. M. Ros (edd.), Navegar el Mediterráneo (Phicaria 6; Universidad Popular de Mazarrón 2018) 17-35.

63 A. Martin Menéndez, "Àmfores tarraconenses i bètiques en els derelictes de mitjan de segle I a.C. a la costa catalana," in SFECAG, Actes du Congrés de L'Escala-Empúries (L'Escala 2008) 103-27.

64 V. Martínez Ferreras, Estudi arqueomètric $i$ arqueològic de la producció $i$ difusió d'àmfores vinàries de la zona central i sud de la costa catalana durant els segles I aC i I dC (Ph.D. diss., Universitat de Barcelona 2008) 78-82.

65 One recovered in 1894 by R. Alfaràs and another spotted by coral fishers in the 1960s. One of those recovered, now in a private collection, weighs $56 \mathrm{~kg}$ (we owe this information to Rut Geli).

66 The amphora is in the private collection of Martínez de la Guardia (Lloret de Mar). The inscription was published as taŕtikeleś: M. del V. Vilà, “Àmfora amb inscripció llatina i grafit ibèric," Pyrenae 27 (1996) 295-99.

67 Many of the amphoras from this wreck are in the Guerra collection. We thank Albert Martin for information linking the inscribed amphoras with the Cala Bona I wreck.

68 Vilà (supra n.66).

69 Martin Menéndez (supra n.63). 
variant is also recorded on amphoras of the same type at baitolo/Baetulo in contexts from 40 B.C. onwards. ${ }^{70}$

A lead sheet from Gruissan (B.3.2) is considered to be part of the cargo carried by the Grand Bassin B (Étang de Mateille). This attribution hinges on the location where the sheet was found, but it has no archaeological context. This ship was primarily carrying Dressel 1A (31 specimens), but two Pascual 1 have also been recorded, one bearing the stamp Mevi. From the same wreck came the toe of a Greco-Italic amphora with a possible pre coctionem graffito in Iberian (there are only two signs) that to judge from the published drawing could be read as le. ${ }^{71}$ Fragments of black gloss pottery, four coins from the mint of kese (BDH Mon-12) and a large bronze plate with the Celtiberian inscription [---]ikum steniotes ke rita (K.17.1) were also recovered. The chronology proposed for this wreck is the first third of the 1st c. B.C., but the presence of Pascual 1 amphoras does not fit since their production started around 40 B.C. It is thus likely that two different wrecks exist, as Y. Solier and A. Gorgues already suspected..$^{72}$ The contents of the lead sheet are not clear but, as is demonstrated by the lead sheets written in Greek from Empúries (L'Escala) ${ }^{73}$ and Pech Maho (Sigean) ${ }^{74}$ dated to the 5 th c. B.C., this type of document can be interpreted as commercial letters with indications related to maritime businesses. The letters mentioned various individuals whose names are unequivocally Iberian: ${ }^{75}$ on the sheet from Empúries $\mathrm{B} \alpha \sigma \pi \varepsilon \delta\left[\right.$ is mentioned twice as one of the intermediaries, ${ }^{76}$ while on that from Pech Maho several individuals, all of Iberian origin - such as B $\alpha \sigma \iota \gamma \varepsilon \varrho \varrho \circ$, , Го $\lambda \mathrm{o}[.] \beta \mathrm{t} \varrho \mathrm{Q}$ and $\Sigma \varepsilon \delta \varepsilon \gamma \omega \nu$ - act as witnesses certifying the payments realized during the commercial transaction.

Interpretation of amphora stamps remains controversial: ${ }^{77}$ for some scholars, they refer to the potters, for others the producers of the product traded or those who traded it. Perhaps different interpretations are valid depending on the particular case; they may even be

70 M. Comas, Baetulo. Les marques d'àmfora (Badalona 1997).

71 Y. Solier (ed.), "Les épaves de Gruissan," Archaeonautica 3 (1981) 1-264; A. Gorgues, Économie et société dans le Nord-Est du domaine ibérique (IIIe-Ier s. av. J.-C.) (Anejos AEspArq 52; 2010).

72 Solier ibid. 61; Gorgues ibid. 316.

73 E. Sanmartí Grego and R. A. Santiago, "La lettre grecque d'Emporion et son contexte archéologique," RANarb 21 (1988) 3-17.

74 M. Lejeune, J. Pouilloux and Y. Solier, "Etrusque et Ionien archaïque sur un plomb de PechMaho (Aude)," RANarb 21 (1988) 19-59; A. Gorgues, "Trade in a liminal zone. Commercial encounter and transformation in the Iron Age North West Mediterranean," Archaeolingua 39 (2016) 167-210.

75 M. Miró and M. Santos, "The Greek presence on the east coast of the Iberian peninsula: colonial establishments and rhythms of trade with Iberian societies," Catalan Hist. Rev. 7 (2014) 9-28; M. J. Pena, “Quelques réflexions sur les plombs inscrits d'Emporion et de Pech Maho. Pech Maho était-il un comptoir du sel?," REA 116 (2014) 3-21.

76 Initially, $\mathrm{B} \alpha \sigma \pi \varepsilon \delta$ was considered to be Phoenician, but Baspedas has recently been re-interpreted as an Iberian personal name, perhaps basbedin, a hypothesis that we believe is correct: J. de $\mathrm{Hoz}$, "El comercio en época arcaica y clásica: los grafitos y las cartas de plomo," in $\mathrm{M}^{\mathrm{a}} \mathrm{Paz}$ de Hoz (ed.), El Oriente griego en la península ibérica: epigrafía e historia (Madrid 2013) 43-60; J. Velaza, "Basped- sur le plomb grec d'Emporion: un anthroponyme ibérique?" Beiträge zu Namenforschung 27 (1992) 264-67.

77 P. Berni, "Dinámica socioeconómica en la tarraconense oriental a finales de la república y comienzos del Imperio. El comercio del vino a través de la epigrafía anfórica," in Tarraco biennal: Actes 1er Congrés int. d'arqueologia i món antic (Tarragona 2013) 63-83; R. Járrega, "Ánforas vinarias en el este de la Hispania Citerior en época tardorrepublicana (siglo I a.C.): epigrafía anfórica y organización de la producción," SPAL 24 (2015) 77-98. 


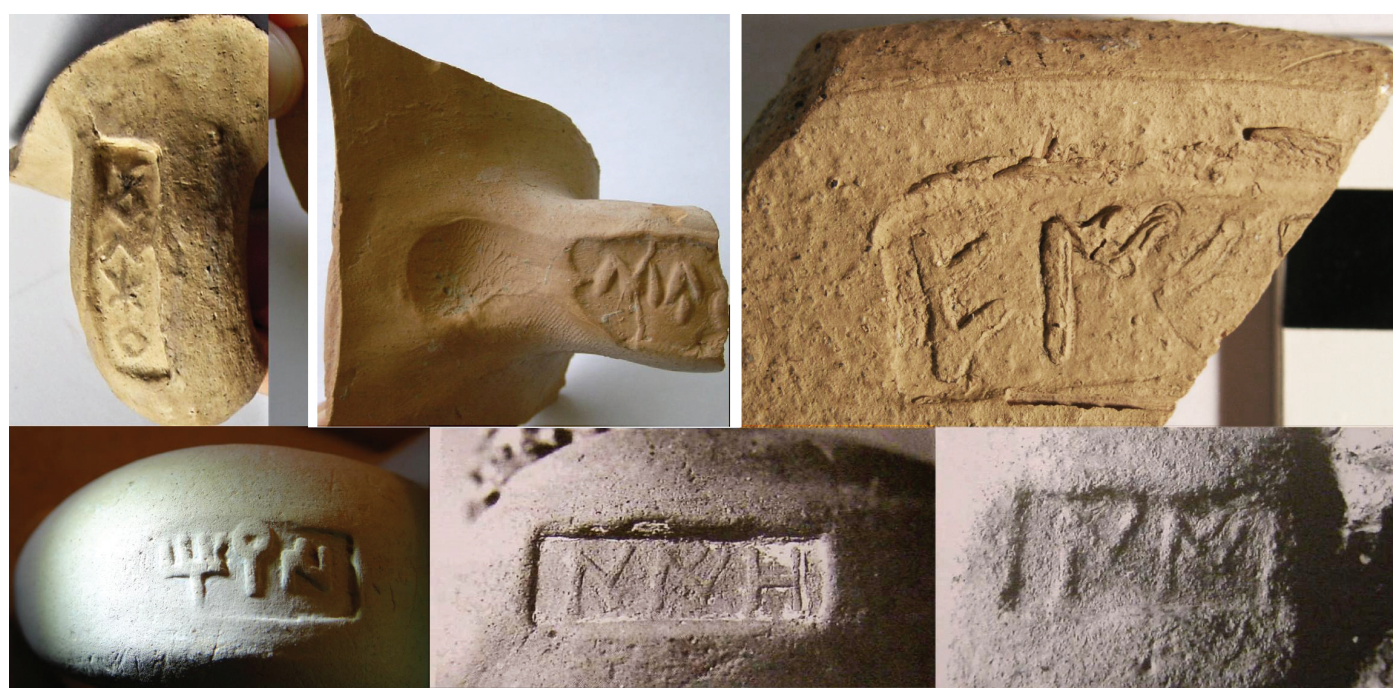

Fig. 8. Iberian stamps on amphoras: aŕkeboŕ (J. Ferrer), śube[ (J. Ferrer), eikebi[ (BDH), tiŕi $(B D H)$, and nio (2) (Carreté et al. [infra n.78]).

compatible where potter and producer were the same individual. Nonetheless, there is no doubt that the stamps relate to wine production and commercialization. Iberian inscriptions on amphoras, practically all post coctionem, number over 200. Very different is the case of Iberian stamps made during the production process, of which only 6 are known. The oldest, with the text tiri (B.1.369), marked an amphora of local production that imitated a Greco-Italic type from Ensérune and is dated to the 4th-3rd c. B.C. Two more stamps using Iberian script were recorded on the handles of two Dressel 1 Citerior amphoras from Masmolets (Valls) ${ }^{78}$ and are the oldest recorded in the east of the peninsula (early 1st c. B.C.); indeed, they are among the few examples known for this period, even if we count three known Latin stamps. ${ }^{79}$ The two Iberian stamps have the same text, nio (BDH T.03.01-02), corresponding to a common particle in the construction of Iberian personal names (nios), such as baisenios (C.0.2). A third stamp, from Cal Rubió (Santa Maria i els Monjos), this time on an Iberian amphora dated to the 2nd-1st c. B.C., bears the Iberian personal name aŕkeboŕ (C.19.2) (fig. 8). Dated to the end of the 1st c. B.C. is an amphora from Guissona (Iesso), another ex novo foundation of the early 1st c. B.C. (fig. 5); it carries a stamp with the mark śube[ (BDH L.18.14) which has no clear parallels and is hard to interpret. The only Iberian stamp known on a Layetana 1/Tarraconense 1 amphora, from a context of c.50-40 B.C. at Zaragoza, has eikebi[ (BDH Z.10.02) marked on the rim, which must be an Iberian personal name, perhaps eikebi[ứ] or eikebi[los]. It may be of interest here that eikebi[ has been taken as a member of the Iberian élite and owner of a fundus. ${ }^{80}$ This example points to fluvial trade by way of the Ebro: a product made and packed in the territory of the Cessetani or the Laaetani was transported as far as salduie/Sallvie (Zaragoza) in the territory of the Sedetani.

Another type of inscription bringing information about maritime trade are those painted on Greco-Italic amphoras from Vieille-Toulouse (BDH HGA.01.01-35). Dated to territory of Tarragona, Spain 1985-1990 (JRA Suppl. 15, 1995) 81-82, figs. 5.14-15; Berni ibid. 65.

79 Berni ibid.; Járrega (supra n.77) 79.

80 M. C. Aguarod, “Un ánfora Tarraconense 1/Layetana 1 con sello ibérico procedente de Salduie,” Bol. Mus. Zaragoza 11 (1992) 109, fig. 8. 

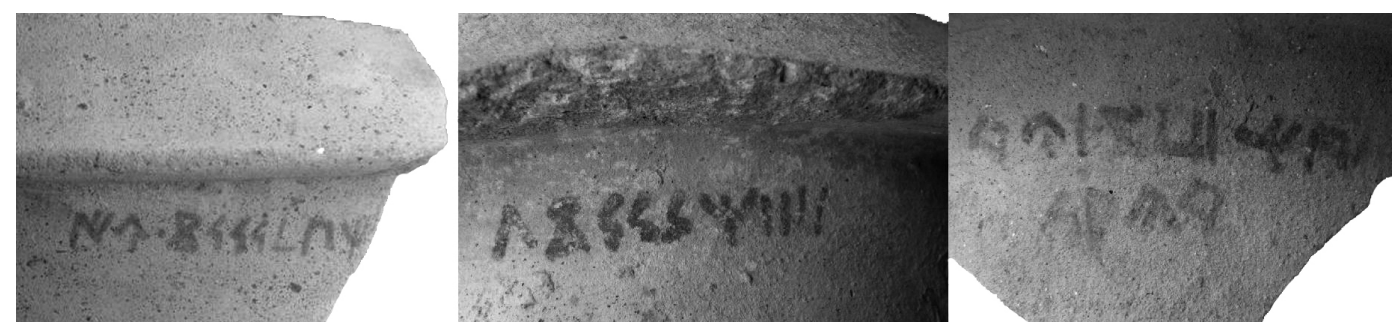

Fig. 9. Inscriptions painted on the Greco-Italic amphoras from Vieille-Toulouse BDA HGA.01.35, 12 and 17 (BDH).

the mid-2nd c. B.C. (fig. 9), they contain personal names followed by a metrological expression (always the same one for each name when several examples are preserved) ${ }^{81}$ While these texts use the Iberian script, they represent Latin names (babirki/Fabricius; binuki/ Minvcivs; kurti/Curtivs; śeśte/Sextvs); just one name (Q. OFELI) is written directly in Latin. Only sakaŕ seems to be an Iberian personal name, but its context is different since it appears in isolation in the second line and is not followed by any metrological expression. Many interpretations of these metrological expressions have been proposed: capacity, volume destined for a client, number of amphoras in the lot, date, price, lot number, etc. As the inscriptions are written on Italic wine amphoras, it seems plausible to suggest that the inscription in Iberian was added during the commercialization process, probably at the port (Narbonne or Empúries?) where the amphoras were unloaded. If so, Iberian individuals may have participated at a point in the wine's commercialization. Lastly, an amphora operculum from Ensérune (B.1.330) with a fragmentary text ] tuŕ [o] ŕtu [, known only from a drawing, has been read as Iberian. If correct, the participation of Iberian-speaking peoples during the packaging process (who are normally also the producers) would be attested. This might not be an isolated case if two opercula with possible Iberian stamps on display in the Ensérune museum are indeed texts in the Iberian script, although this is unclear.

In short, participation in maritime commerce by individuals who used the Iberian language can be documented from at least the 5th c. B.C., thanks to the references on lead sheets to individuals such as Basigerros who acted as witnesses to commercial operations recorded in the sheet from Pech Maho, as well as intermediaries like $\mathrm{B} \alpha \sigma \pi \varepsilon \delta$ [ recorded on the sheet from Empúries. That this pattern continued seems to be shown by some of the Iberian lead sheets: this is known to be the case with the lead sheet from Gruissan (B.3.2) which originates from a wreck dated to the 1st c. B.C. Painted inscriptions on Italic amphoras at Vieille-Toulouse that had presumably been unloaded at Narbonne or Empúries in the mid-2nd c. B.C. reflect Iberians participating in the process of commercializing imported products, in this case perhaps by an individual named sakaŕ. Iberian stamps on Dressel 1 amphoras from Citerior and the Layetana 1/Tarraconense 1 demonstrate the participation of natives such as nio and eikebi[ in the production process in the 1st c. B.C. The latter was perhaps also the owner of the wine production itself. This finds support in the stamp on the operculum sealing an amphora at Ensérune (B.1.330). Finally, graffiti made post coctionem, such as the one on the Tarraconense 1 amphora from Lloret de Mar, indicates that Iberians, in this case tautibeleś, participated in the wine commercialization process in the second half of the 1st c. B.C. Our lead stock, unique in its category, adds the participation of Iberian-speakers in another stage of the wine trade, as shipowners.

81 Gorgues (supra n.71) 309-25; M. Vidal and J. P. Magnol, “Les inscriptions peintes en caractères ibériques de Vieille-Toulouse," RANarb 16 (1983) 11-28; M. Lejeune, "Vieille Toulouse et la métrologie ibérique," ibid. 29-37. 


\section{Iberian shipowners? The Cap del Vol and Cala Cativa I wrecks}

Was this an isolated case? Let us consider what is currently known about ships and indigenous shipowners. Perhaps the best evidence from Citerior during the Late Republican period is the wreck known as Cap del Vol (fig. 5). ${ }^{82}$ Found in the municipality of El Port de la Selva (Empordà), where its voyage came to a tragic end, it has been interpreted as a vessel from baitolo/Baetulo sailing to Narbonne. Because the site was subjected to severe plundering in the late 1960s, its main cargo, between 200 and 400 Pascual 1 amphoras, some bearing M. Porci and Ivli Teophil stamps, is now scattered (cf. fig. 10 for the original distribution of these stamps). However, the ceramic assemblage recorded during the excavations of 1978-80 allowed the sinking to be dated to between the closing years of the 1st c. B.C. and the first years of the 1st c. A.D. ${ }^{83}$ Despite detecting broad similarities with other wrecks from the W Mediterranean (the vessel made use of certain shipbuilding techniques that are now well-defined), ${ }^{84}$ researchers were able to attribute the degree of specialization of certain techniques to a specific shipyard's practice. Noticeable differences were detected in the details of the vessel's construction: "podría presentar rasgos de hibridación cultural entre lo indígena de la península ibérica y el mundo mediterráneo". ${ }^{85}$ This conclusion, based exclusively on the study of the naval architecture, is reinforced by the Iberian coin having an apotropaic function that was placed at the base of the mast. It would have come from the bolśken mint (BDH Mon-30), ${ }^{86}$ although for some scholars it was possibly a

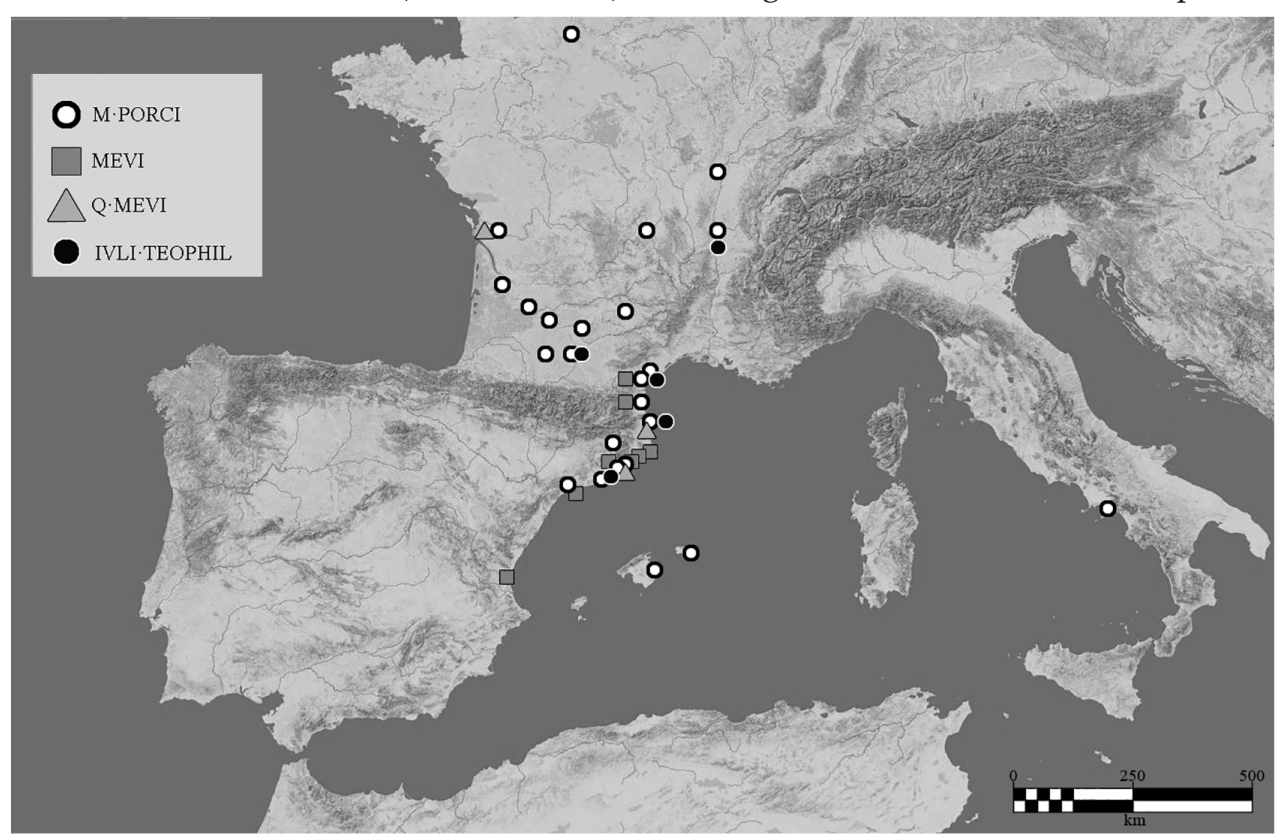

Fig. 10. Distribution of the stamps M.Porci, Mevi, Q.Mevi and Ivli.Teophil on amphoras Layetana 1 and Pascual 1 (CAncient World Mapping Center, map prepared by C. Palacín [CEIPAC]).

X. Nieto, “El pecio romano del Cap del Vol. Nuevas aportaciones," Cypsela 4 (1982) 165-68; Vivar et al. (supra n.48).

83 Nieto ibid. 168.

84 P. Pomey, “Une nouvelle tradition technique d'assemblage antique: l'assemblage de la membrure par ligatures et chevilles," in H. Tzalas (ed.), Tropis VII. 7th int. symposium on ship construction in antiquity, vol. II (Athens 2002) 597-604.

85 Vivar et al. (supra n.48) 101 and 106.

86 J. Blay, "Monedas votivas en el pie de mástil de navíos romanos," Gaceta Numismática 155 (2004) $5-13$. 
coin from arse (BDH Mon-33). ${ }^{87}$ This practice has been seen as another sign of indigenous cultural hybridization with a Roman ritual, even if we set aside the question of the appropriateness of the term "hybridization" when defining a set of practices that remain poorly known. At any event, the Cap del Vol wreck displays features that allow us to suggest the possible existence of local owners. Note also that the vessel at Cap del Vol was originally from baitolo/Baetulo, the town that the inscription in our stock seems to mention.

A second wreck, the Cala Cativa I (fig. 5), is also relevant. In late 2016, archaeologists of the Centre d'Arqueologia Subaquàtica de Catalunya (CASC) began an underwater excavation on a $10 \mathrm{~m}$-long wreck in the waters of Cap de Creus, immediately off the shore of El Port de la Selva (Alt Empordà). Dated to c.40-30 B.C., its principal cargo was composed of some 150-200 Pascual 1 amphoras. Initial study of its naval architecture indicates that it shows signs of the same building tradition recorded at Cap del Vol. This tradition seems to fulfil the aim of building vessels capable of sailing both in open waters and in marshes and lagoons. As one of the excavators said:

Es la evolución perfecta que necesitábamos, al ser más pequeño y más antiguo [que el Cap del Vol, $15 \mathrm{~m}$ de eslora] defiende nuestra teoría [de barcos de tradición indígena]. ${ }^{88}$

TABLE 1

WRECKS WITH COINS RECORDED UNDER THE MAST

\begin{tabular}{rlll} 
& Wreck & Chronology & Coin type \\
\hline 1 & Chrétienne A & 2nd half of 2nd c. B.C. & Punic coin from Cosura \\
\hline 2 & Spargi & Last quarter of 1st c. B.C. & Illegible \\
\hline 3 & Cavalière & End of 1st c. B.C. & 3 illegible coins \\
\hline 4 & La Madrague de Giens & Mid-1st c. B.C. & Sextans of Rome \\
\hline 5 & Plane 1 & Mid-1st c. B.C. & Unit of kese \\
\hline 6 & Titan & Mid-1st c. B.C. & Roman semi-unical as \\
\hline 7 & Cap del Vol & Turn of the era & Unit of bolśken \\
\hline 8 & Diano Marina & Mid-1st c. B.C. & Not specified \\
\hline 9 & Blackfriars & End of 1st c. A.D. & Domitian as \\
\hline 10 & Calanque de l'Âne & End of 1st c. A.D. & Domitian as \\
\hline 11 & Pointe de Luque & 2nd c. A.D. & 2 coins of Hadrian \\
\hline 12 & Grado & Mid-2nd c. A.D. & Illegible bronze coin \\
\hline 13 & L'Anse Gerval & 4th c. A.D. & Coin of Constantine I \\
\hline
\end{tabular}

\section{Coins under the mast}

The tradition of placing coins in the cockpit hole is well documented in Roman-era ships, ${ }^{89}$ even if in some cases the mast has been recovered without the presence of coins, showing that the practice was not ubiquitous. The existing corpus has 13 wrecks: of the 13, six use Roman coins, two use Iberian and one uses Punic; in three cases the coin used

87 G. Vivar, C. de Juan and R. Geli, Cap del Vol. Un producte, un vaixell i un comerç de la Tarraconense a l'êpoca d'August (Museu d'Arqueologia de Catalunya 2013); https://es.slideshare.net/ macarqueologia/cap-del-vol-un-producte-un-vaixell-i-un-comer-de-la-tarraconense-a-lpocadaugust (viewed Sept. 18, 2019).

88 https://elpais.com/ccaa/2015/10/06/catalunya/1444164898_572579.html

89 Blay (supra n.86); D. N. Carlson, "Mast-step coins among the Romans," IJNA 36 (2007) 317-24, with bibliography. 
cannot be determined, and in one case it remains unknown. The presence of Iberian coins at the base of the mast raises three possible explanations. First, in light of their apotropaic/ symbolic rôle, it suggests that the shipowner chose the currency, in which case he will have done so based on his own knowledge of what this coin represented (e.g., a divinity on it; thus, the coin on the Blackfriars wreck had the image of Fortuna). Second, the currency could have referred to the owner's place of origin or the place of the ship's construction. Third, if we take the contrary view that the coin does not lead to an idea of the identity of the person who placed it there, it may have been used simply for the sake of a ritual practice, as a low-value coin taken from those in ready circulation at the place of the ship's construction (as seems also to be the case with many coins placed in burials). ${ }^{90}$

The bolśken coin recovered from the Cap del Vol wreck is an old, worn piece. ${ }^{91}$ It is consistent with a shipwreck occurring around the turn of the era. In Citerior, Iberian coinage circulated much more than Roman currency between the last quarter of the 2nd c. and 72 B.C., when most of the mints ceased activity, although kese, undikesken and perhaps ildiŕda were still minting in the mid-1st c. B.C. ${ }^{92}$ Indeed, Iberian coinage is found not only in contexts of the second half of the 1st c. B.C., but also as late as the late 1st c. A.D. ${ }^{93}$ On the other hand, the coin of kese (BDH Mon-12) from the Plane 1 wreck was better preserved, a circumstance again consistent with a shipwreck of the mid-1st c. B.C. ${ }^{94}$ and coinciding well with the last bronze coins issued by that mint. This wreck also displays shipbuilding features that are compatible with those in the Cap del Vol and Cala Cativa I wrecks. ${ }^{95}$ In short, the Iberian coins reinforce the idea of ships built locally and operated by indigenous Iberian individuals.

\section{Final remarks}

The first anchor stock bearing an Iberian inscription adds a new material support and a new engraving technique to the corpus of such inscriptions. More importantly, it adds to our understanding of the rôle that the native peoples of NE Spain played in the maritime trade of the W Mediterranean and particularly the wine trade of the 1st c. B.C. Although the typology of the anchor does not help date the inscription, the palaeography falls within the general framework of the Iberian non-dual script (2nd-1st c. B.C.). Iberian inscriptions in general are rare after the mid-1st c. B.C., but as it was precisely during this period that the wine trade is first documented a date in the second half of the 1st c. B.C. seems likely.

We have argued that the word baitolo is a place-name, whether a town or a river name. While personal names are the most common on lead stocks, usually naming the vessel's owner, the possibility that baitolo is a personal name is unlikely due to the low frequency

90 A. Arévalo et al., “Contrastación del registro numismático en los rituales funerarios ebusitanos, gadeiritas y malacitanos," in A. Arévalo (ed.), Monedas para el más allá: uso y significado de la moneda en las necrópolis tardopúnicas y romanas de Ebusus, Gades y Malaca (Cádiz 2016) 251-78.

A. Tchernia, "Contre les épaves. Gaule interne et Gaule méditerranéenne aux II et I siècles avant J.-C.," in A. Duval, J.-P. Morel and Y. Roman (edd.), Gaule interne et Gaule méditerranéenne aux IIe et Ier siècles avant J.-C.: confrontations chronologiques (Paris 1990) 294.

92 M. Campo, "La moneda ibérica en el nordeste de la Citerior," in Sinner (supra n.13) 27.

93 M. Campo and J. Ruiz de Arbulo, "Conjuntos de abandono y circulación monetaria en la Neápolis emporitana," Empúries 48-50 (1986-89) 152-63; A. G. Sinner and C. Martí, “La circulación monetaria en el valle de Cabrera de Mar (El Maresme, Barcelona)," in Sinner (supra n.13) 55-71. 
of the formants bai and tolo in the composition of Iberian anthroponyms. It may, however, be the name of a deity, since the river named baitolo could have had an associated divinity. Nevertheless, to date there are no compelling arguments to support this theory if we take into account what is known about the Iberian pantheon and language. ${ }^{96}$ In sum, the most plausible scenario is that the text baitolo on the stock is the name of the ship, named after the river, or, more likely, the city where the vessel was built.

For the broader study of the cultural, social and economic development of NE Spain in the 2nd-1st c. B.C., the lead stock is a key document for exploring the participation of Iberians in maritime trade and the existence of local shipyards and shipowners. We have traced the participation in commercial enterprises by indigenous individuals from the 5 th c. B.C. From the mid-2nd c. painted inscriptions show Iberian-speakers participating in the commercialization of imports, before a local production of wine began in NE Spain. Once that began, Iberian stamps reflect their participation in the amphora production process and perhaps as owners of wine-producing estates. Subsequently, post-coctionem graffiti on amphoras indicate that natives participated in the wine commercialization process at the port of origin. Our lead stock with the double Iberian inscription baitolo now confirms that Iberians took part in the maritime operations. We may thus speak authoritatively of local shipyards and Iberian shipowners, as was already suspected after the excavation of the Cap del Vol and Cala Cativa I wrecks. It is now evident that native peoples of NE Spain participated in all the phases of the chaîne opératoire (production, packaging, transport both terrestrial and maritime, etc.) that resulted in the commercialization of large amounts of wine to SW Gaul, especially Narbonne, and from there to Britannia and elsewhere. They did so by building ships suited for navigation along the coast as well as in the marshes and lagoons that are frequent along the cabotage route between the Ebro and Narbonne, with baitolo/Baetulo (Badalona) and the surroundings of the homonymous river (Besòs) as one of the main centres of operation.

agsinner@uvic.ca Department of Greek and Roman Studies, University of Victoria, BC joan.ferrer.i.jane@gmail.com Departament de Filologia Llatina, Universitat de Barcelona

\section{Acknowledgements}

We would like to thank Mr. Salvador Guerra for allowing us to visit his collection on several occasions, as well as for all the facilities provided on each visit. Without his collaboration, this article would have never been possible. We wish to thank Albert Martín (archaeologist of Cabrera de Mar town hall) for his collaboration, and Víctor Revilla (Universitat de Barcelona), Javier Velaza (Universitat de Barcelona), Cesar Carreras (Universidad Autónoma de Barcelona), Pepita Padrós (Museu de Badalona), Rut Geli (CASC), Gustau Vivar (CASC), Carlos de Juan (Universitat de València) and Víctor Sabaté (Universitat de Barcelona) as well as two anonymous readers for their comments on earlier versions of this article, which have all helped to improve the final text.

For A. Sinner, this article is part of the research project "Beyond contacts: tracing identities and cultural change in the Roman West" (http://orcid.org/0000-0002-5816-5794), funded by the Social Science and Research Council of Canada thanks to an Insight Grant. For J. Ferrer, this article is part of the research project FFI2015-63981-C3-1-P “Hesperia: lenguas, epigrafía y onomástica paleohispánica" (https://orcid.org/0000-0002-6596-7437), funded by the Ministerio de Economía y Ciencia.

96 Arguments against interpreting the text baitolo as a deity are given in Ferrer and Sinner (supra n.2) $154-55$. 